\title{
Response of Citrus Slow Decline Causing Nematode ( $T$. semipenetrans) against Different Cultivars (Kinnow, Musambi, Shakri, Feutrel Early, Red Blood) of Citrus
}

\author{
Yasir Ali ${ }^{1}$, Ghulam Abbas ${ }^{2, *}$, Muhammad Sajid ${ }^{2}$, Muhammad Imran $^{3}$ \\ ${ }^{1}$ Department of Plant Pathology, University of Agriculture Faisalabad, Pakistan \\ ${ }^{2}$ Department of Animal Production, Riphah College of Veterinary Sciences Lahore, Pakistan \\ ${ }^{3}$ Faculty of Veterinary Sciences, Riphah College of Veterinary Sciences Lahore, Pakistan
}

Copyright $(2018$ by authors, all rights reserved. Authors agree that this article remains permanently open access under the terms of the Creative Commons Attribution License 4.0 International License

\begin{abstract}
The intent of the present study was to investigate the effect of citrus slow decline causing nematode (T. semipenetrans) against different cultivars (kinnow, musambi, shakri, feutrel early and red blood) of citrus in earthen pots (kinnow, musambi, shakri, feutrel and red blood) were filled with formalin sterilized soil. The sterilization of sandy loam soil (72\% sand, $17 \%$ silt and $8 \%$ clay) was accomplished by applying formalin. Diluted formalin (1:320) was poured on the small heap of soil and covered with polythene sheet to stop the fumes completely. Soil treated with water was kept as control. Each treatment was replicated 3 times. Varieties (kinnow, musambi, shakri, feutrel and red blood) were transplanted into these pots. The pots were completely randomized, kept in the glass house and watering was done to avoid drying of soil. After fifteen days, $2000 \pm 25$ freshly hatched juveniles in $15 \mathrm{ml}$ of water were added around the stem of plant of each pot by making holes and then filled with soil to prevent drying. Then they were watered carefully. Over irrigation of the pots was avoided. Experiment was harvested after ninety days. Experiment was repeated twice to confirm the results. The association of inoculated pathogens was confirmed by re-isolation. Survey results showed that maximum $T$. semipenetrans occurrence was in tehsil Sargodha (90\%), Kot Momin (80\%), Bhalwal $(60 \%)$ and minimum prevalence was in sillan wali $(50 \%)$.
\end{abstract}

Keywords Effect, Citrus, Kinnow, T. semipenetrans, Sargodha

\section{Introduction}

Pakistan is basically an agricultural economy and agriculture contributes $21.4 \%$ to GDP of the county. Agriculture is the major source of employment (47\% of the country's people, and $75 \%$ of rural population) of people [12]. Citrus is one of the major fruit of the world which is growing throughout the globe due to its significant nutritional (rich source of sugar, organic acids, amino acids, vitamin $\mathrm{C}$ and minerals) effect on human health. Pakistan is amongst the well-known producer of citrus; however, its yield is affected due to attack of insects and pathogens (nematode, fungal, bacterial and viral) which causes heavy losses both in quality and quantity.

Plant parasitic nematodes (T. semipenetrans) have stylet which penetrates into host plant and punctures its tissues for the absorption of nutrientsand causes yield losse (10-30\%. Anwar and Sarwar [1] reported the prevalence of $T$. semipenetrants in Faisalabad. They investigated that T.semipenetrans are major contributor of decline of citrus plantation in Punjab.T. semipenetrans caused "slow decline" (decline in growth of tree, and small fruit size.) on citrus trees also damage the integrity of the epidermis and cortex of the roots which may invite to other pathogens attack [4]. Therefore this project was designed to investigate the eeffect of citrus slow decline causing nematode ( $T$. semipenetrans) against different cultivars (kinnow, musambi, shakri, feutrel early and red blood) of citrus to screen out the most susceptible variety of citrus against $T$. semipenetrans.

\section{Material and Methods}

\section{Sources of Material: Nematodes}

Citrus slow decline nematode (Tylenchulus semipenetrans) was obtained from a single egg mass isolated from infected citrus roots collected from citrus 
orchards area of Sargodha and maintained at the glasshouse whilst sterilized soil were used was used in the study for all experimental pots.

\section{Survey}

\section{Location of Experimental Sites}

The occurrence of $T$. semipenetrans was observed in Sargodha district for exploiting the interaction of citrus nematode $T$. semipenetrans and Fusarium spp. in relation to citrus slow decline. A survey was carried in different citrus fields of Sargodha district (Sargodha, sillanwali, bhalwal, kot Momin and shah pur). The orchards were selected randomly from different locations of Sargodha district and 7 to 35 years old orchards were selected. Samples were taken from these orchards 6 times (February, April, June, August, May, July, October, and December).

\section{Data Collected at Sites}

Plants from different orchards were selected on the basis of symptoms like less new foliage, yellowing of leaves, poor nutritional symptoms, very poor growth of tree. The $\mathrm{pH}$ of soil, soil moisture and environmental temperature were noted. Samples after collection were carried to plant pathology laboratory of University College of Agriculture Sargodha for further process.

\section{Sampling Soil and Root System in the Orchards}

Soil sample was taken when soil moisture was suitable. Sampling under excessive dry and wet conditions was avoided. Sampling depth for citrus trees was 8-12 inches. Soil sample was collected at a distance of 30 to $90 \mathrm{~cm}$ away from the trunk. Sample was collected from feeding roots. Soil and root samples were collected using a $17 \mathrm{~mm}$ auger.

To avoid dryness, samples were stored in plastic (polythene) bag. The samples were properly labelled recording farmer name, date, location, etc. To avoid high temperature, samples were collected in the morning time. Nematodes could die from friction and shock so samples were handled with care. Samples were processed as soon as possible because storage could cause changes in number of nematode population. Then sample were brought to Plant Pathology Lab, University College of Agriculture, for further process and stored in a cool incubator (Raypa, Made in Spain) at $10{ }^{\circ} \mathrm{C}$ for further processing.

\section{Extraction Method of $T$. semipenetrans}

Both whitehead and hemming tray method and baermann tray method were used for the extraction of $T$. semipenetrans.

\section{Whitehead and Hemming 1965}

Covered the perforated bowl with tissue paper and placed the soil or roots in that bowl and then placed on the non-perforated bowl having water. Water just touched the surface. Then kept it for 24 hours and incubated at $25-28^{\circ} \mathrm{C}$. After 24 hours water was collected in beaker and allowed settling of juveniles for one hour. When nematodes were settled excessive water was siphoned, until $100 \mathrm{ml}$ water remained.

\section{Baermann Funnel Method}

Baermann funnel consisted of sieves made out of nylon gauze and fixed onto plastic ring. Tissue paper was placed on the top of nylon gauze. Then place the soil sample or root sample on the sieve. For root samples the roots were cut into $1-2 \mathrm{~cm}$ parts and then sieve with water on a glass funnel in contact. Water was enough to touch the sieved. Nematodes were moved into water after 24 hours. Water suspension was collected for further process. This process was repeated 2-3 times. Temperature was kept during that process at $25-28^{\circ} \mathrm{C}$.

\section{Counting of Nematode Suspension}

While counting the nematode population, for accurate and more precise results, all the samples were made up to equal volumes during the survey and experiment. Volume was kept at $50 \mathrm{ml}$. Large samples were then left for few hours to settle down the juveniles. Then excessive water was siphoned until the required volume remained. Before taking each aliquot, the suspension was agitated to ensure an even distribution of nematodes. For each suspension, $3 \mathrm{x}$ $1 \mathrm{ml}$ aliquots were taken and placed in $5.5 \mathrm{~cm} \mathrm{x} 4 \mathrm{~cm}$ counting dishes with $2 \mathrm{~mm} \times 4 \mathrm{~mm}$ squares. For macerated root suspensions, a pipette with a wide $(2 \mathrm{~mm})$ opening was used. Root pieces were found to clog up smaller pipette openings. The number of nematodes in each aliquot was counted using stereomicroscope. Estimation thus was made of the total number of nematodes in the suspension.

\section{Identification of T. semipenetrans}

\section{Picking of T. semipenetrans from Suspension}

To observe the nematode for identification, it was necessary to pick the individual nematode from the suspension and place on glass slide. Pipette was used to place some nematode suspension into petri dish and then place on a stereomicroscope. Nematode suspension was circulated to move center of dish. Nematode was detected and left with picking tool. When nematode hanged on the tip of picking instrument, the tip of needle was dipped into drop of water on a slide. 


\section{Staining Methods for Egg Masses and Nematodes}

Two staining methods were adopted. T. semipenetrans egg masses were stained using phloxine B and nematodes within roots were stained with Acid fuchsine method. Egg masses of $T$. semipenetrans stained with phloxine B. Roots were washed to remove soil particles and large pieces were cut in to small pieces. Roots were soaked for $15 \mathrm{mins}$ in phloxine B solution $(0.15 \mathrm{~g} /$ litter of water). From the whole root system stained egg masses were counted under a stereomicroscope.

\section{Staining of Nematode with Acid Fuchsine}

For the staining of nematodes plants were watered before sometime of harvesting, because plants roots could easily be harvested without damage of roots. Roots were not pulled strictly. Then roots were brought to Plant Pathology Lab, and washed under running tap water to remove soil particles attached with roots. Roots were washed carefully to avoid breaking of roots tips. Large roots pieces were cut into small pieces. To clear the roots tissues, appropriate amount of chlorine bleach was added $(5.25 \% \mathrm{NaOCl})$ in $50 \mathrm{ml}$ of tap water. The roots were immersed in the $\mathrm{NaOCl}$ solution for four minutes and infrequently stirred. Again the roots were washed in running tap water for 45 seconds. To remove any residues of $\mathrm{NaOCl}$ which may affect with acid fuchsin soaked the roots in water for 15 minutes. Then prepare stock acidfuchsin solution, dissolved $3.5 \mathrm{~g}$ acid fuchsin in $250 \mathrm{ml}$ acetic acid and $750 \mathrm{ml}$ distilled water.

Then put the roots in glass beaker with $50 \mathrm{ml}$ of water. Added $1 \mathrm{ml}$ of acid-fuchsin stain solution into the roots and boiled for 30 seconds on hot plate. The roots were cooled at room temperature and the acid-fuchsin stain solution was drained. Again wash the roots in tap running water. To destain the roots glycerin 20-30ml with few drops of $5 \mathrm{~N}$ $\mathrm{HCl}$ was added and boiled. The roots were placed on petri dish and observed under microscope.

\section{Killing of T. semipenetrans}

To observe nematode on a slide under compound microscope, it was necessary to relax the nematode by heating. Slide was held with forceps over a small flame and then moved for 5-6 seconds. Nematode was carefully watched from time to time to avoid overheating.

\section{Preparation of Temporary and Permanent Slides}

\section{Temporary Slides}

Some nematodes were picked from petri dish and shifted to a drop of water on clean slide. The drop was covered with a cover slip and the edges were sealed with method paraffin-Vaseline or nail polish to prevent rapid evaporation of water.

\section{Permanent Slides (Golden, 1971)}

The nematodes were brought to watch glass with $2-3 \mathrm{ml}$ of water. The specimens were incubated at $42 \mathrm{C}$ for about twelve minutes to relax them. The fixative contained $30 \mathrm{ml}$ formalin, $350 \mathrm{ml}$ distilled water and $8 \mathrm{ml}$ glycerin. After twelve minutes, pouring was done in warm fixative to fill the watch glass almost to the top. Watch glass was removed from oven, covered and maintained at room temperature for twenty four hour. Two drops of saturated aqueous picric acid were added. This stained the style which otherwise became almost invisible in the final preparation. The covered watch glass was maintained at $43 \mathrm{C}$ and was kept at this temperature for 3 weeks or longer. After every two to three days, warm fixative was added as needed to offset evaporation. Three weeks or longer permit the fixative solution to evaporate completely. A few drops of pure, warm (43C) glycerin mount were added in anhydrous glycerin or stored $\mathrm{m}$ sealed vials of glycerin

\section{Identification and Multiplication of T. semipenetrans}

T. semipenetrans identified on the basis of perineal pattern [17]. The root tissue was teased apart with forceps to remove adult females and collected into a drop of $45 \%$ lactic acid in another petri dish. A fully developed female was placed over a clean glass slide and its posterior half of the body was cut off using a surgical scalpel. The lower piece of the cuticle having perineal patterns was further trimmed to square shaped and inner tissue was completely removed by flexible bristle. The perineal pattern-bearing portion was transferred to drop of glycerin on a slide so that the anterior surface was in contact with the glass and the anus was oriented upwards. The glass cover slip was gently placed and sealed with paraffin and labeled. The pattern was examined under a research microscope $[15,16]$.

\section{Nematode Culturing}

\section{Citrus Slow Decline Nematode (Tylenchulus semipenetrans)}

The population of $T$. semipenetrans was collected from the orchards area of Sargodha, Pakistan and maintained on citrus in glasshouse.

Maintenance and transplanting of nursery

\section{Preparation of Soil}

Soil used for pot experiments was obtained from experimental area of University College of Agriculture Sargodha. The soil was air-dried by spreading in a thin layer on plastic sheet in sun. After drying the large stones and plant debris were removed by sieving through $3.5 \mathrm{~mm}$ pore size sieve. After this, mechanical analysis of the soil was performed. Soil used for the experiments was sandy loam (70\% sand, $18 \%$ silt, and $9 \%$ clay) with moisture 
holding capacity (MHC) of $45 \%$. PH of soil ranged from 7-8. Organic matter (4-5\%) also was added. The sterilization of soil was done by adding formalin. The solution of formalin with water was prepared by ratio (1:320). Diluted formalin was transferred into the small hole in soil to avoid evaporation and soil was covered with polythene sheet completely. Soil was covered for one week. Soil was exposed after a week to evaporate the residual of formalin. The soil was mixed properly after interval of time to completely remove of residual effect of formalin and then filled in pots.

\section{Raising of Citrus Nursery}

Five varieties of citrus were selected viz. kinnow, musambi, shakri, feutrel and red blood. Citrus nursery was brought from Citrus Research Institute (CRI) Sargodha. One year old disease free plants were selected on the basis of identical physical appearance to each other like plant height, number of leaves etc. After that nursery was carefully transplanted into pots (14 inch) and one plant was sown in each pot. All pots were settled in the plant pathology research area.

\section{Mass Culturing of T. semipenetrans on Plants in Pots}

One year old citrus plants were transplanted into pots (14 inch) containing sterilized sandy loam soil ( $72 \%$ sand, $17 \%$ silt, and $8 \%$ clay). After two weeks these plants were inoculated with 1500-2000 freshly hatched juveniles by making 3-4 holes (3-cm deep) around each plant with the help of pointed wood [14]. The holes were covered with soil to prevent drying. These plants were not watered just after inoculation and they were kept in individual pots to avoid cross contamination. Throughout the experiment the culture plants were kept in greenhouse where temperatures ranged from $22-35^{\circ} \mathrm{C}$. The plants were watered regularly and protected against pests and diseases.

Data regarding Fresh weight of shoot, Fresh weight of root, Root Shoot ratio, No. of leaves, Plant height, No. of females/gram of roots and No. of $\mathrm{J} 2 / \mathrm{g}$ of roots and number of $\mathrm{J} 2 / 100 \mathrm{ml}$ of soil, were recorded.

\begin{tabular}{ccccc} 
& \multicolumn{2}{c}{ T. semipenetrans prevalence tehsil wise } & Sill an wali \\
A & Bhalwal & Kot Momin & Sargodha & 18 \\
P & 72 & 36 & 162 & 90
\end{tabular}

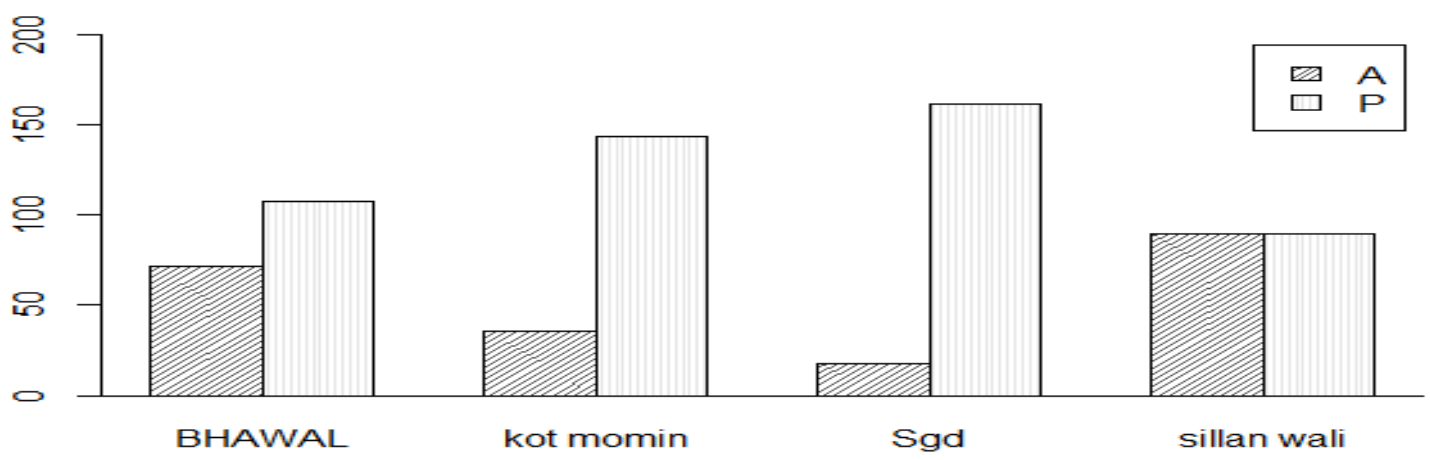




\section{Graph (4.2)}

Graph 4.2 showed that maximum T. semipenetrans prevalence was in tehsil Sargodha and then Kot Momin and minimum prevalence was in sillan wali. During one year survey 180 samples were collected from each tehsil. Infestation was recorded Sargodha, kot Momin, Bhalwal and sillan wali 90\%, 80\%, 60\% and 50\% respectively.

\section{Month Wise T. semipenetrans of J2 Destiny}

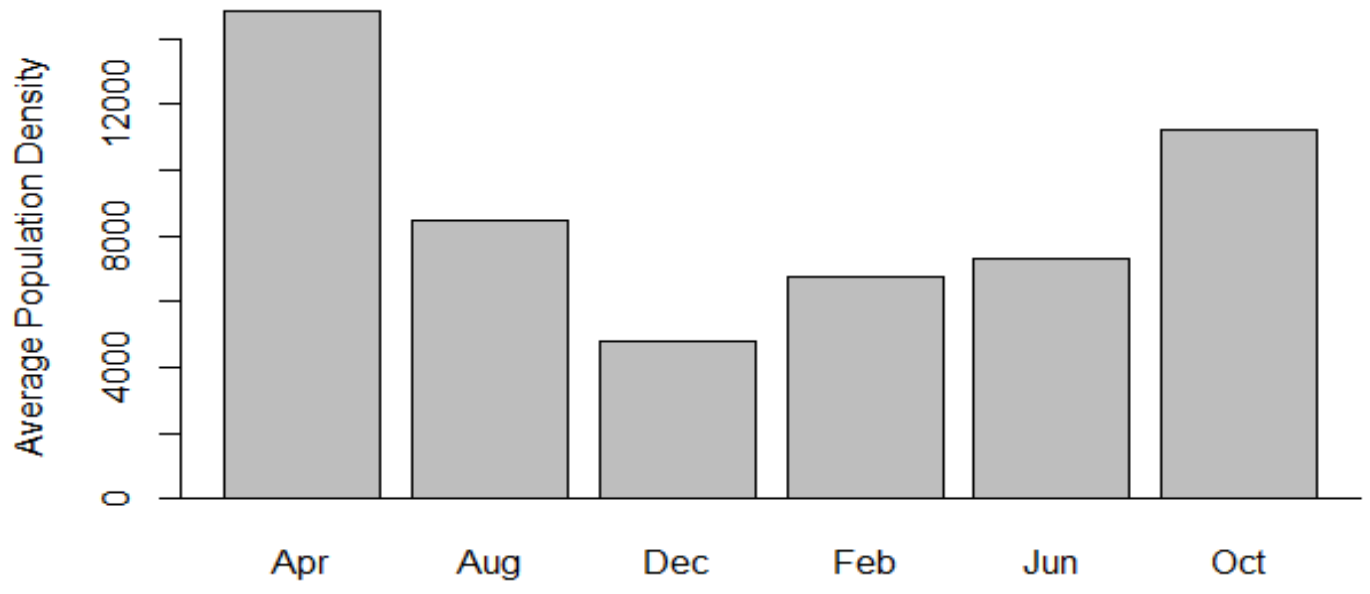

\section{Graph (4.3)}

Graph (4.3) showed Maximum population destiny of T. semipenetrans of J2 was recorded in April at kot Momin 82630 and then in October, minimum population destiny was recorded in December.

\section{Month Wise T. semipenetrans Female's Prevalence}

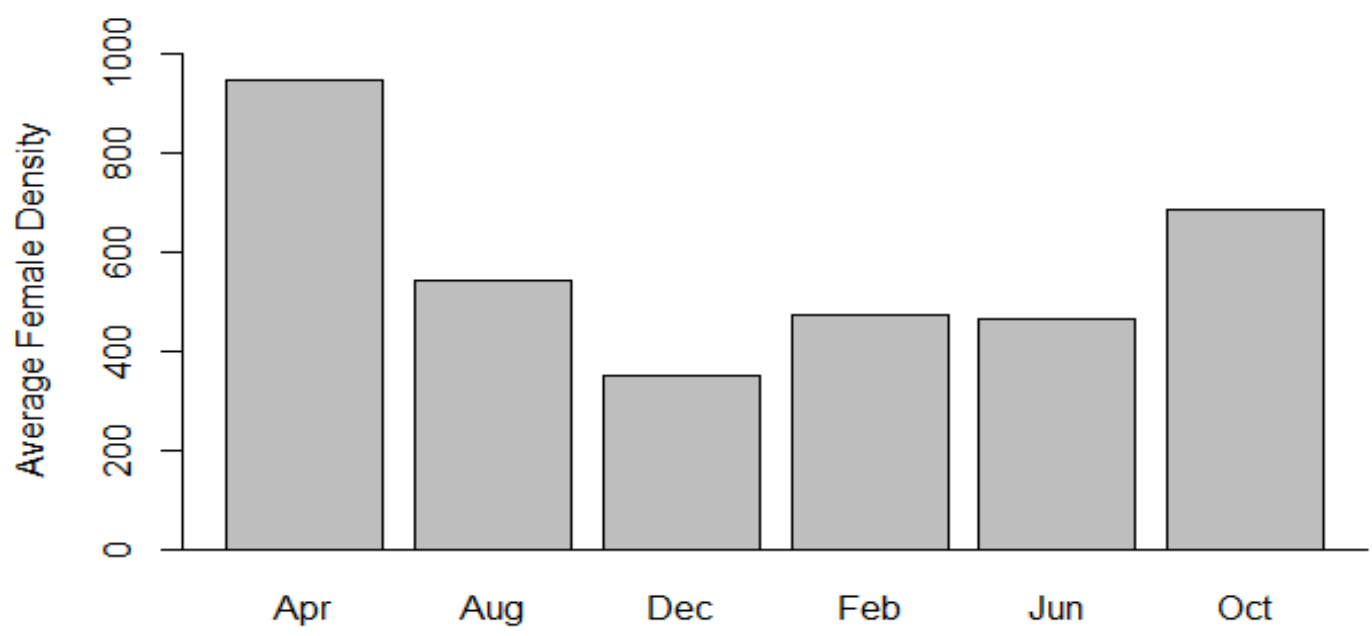

\section{Graph (4.4)}

Graph (4.4) showed Maximum population destiny of T. semipenetrans of females was recorded in April and then in October, minimum population destiny was recorded in December. 
Temperature Influence on $T$. semipenetrans

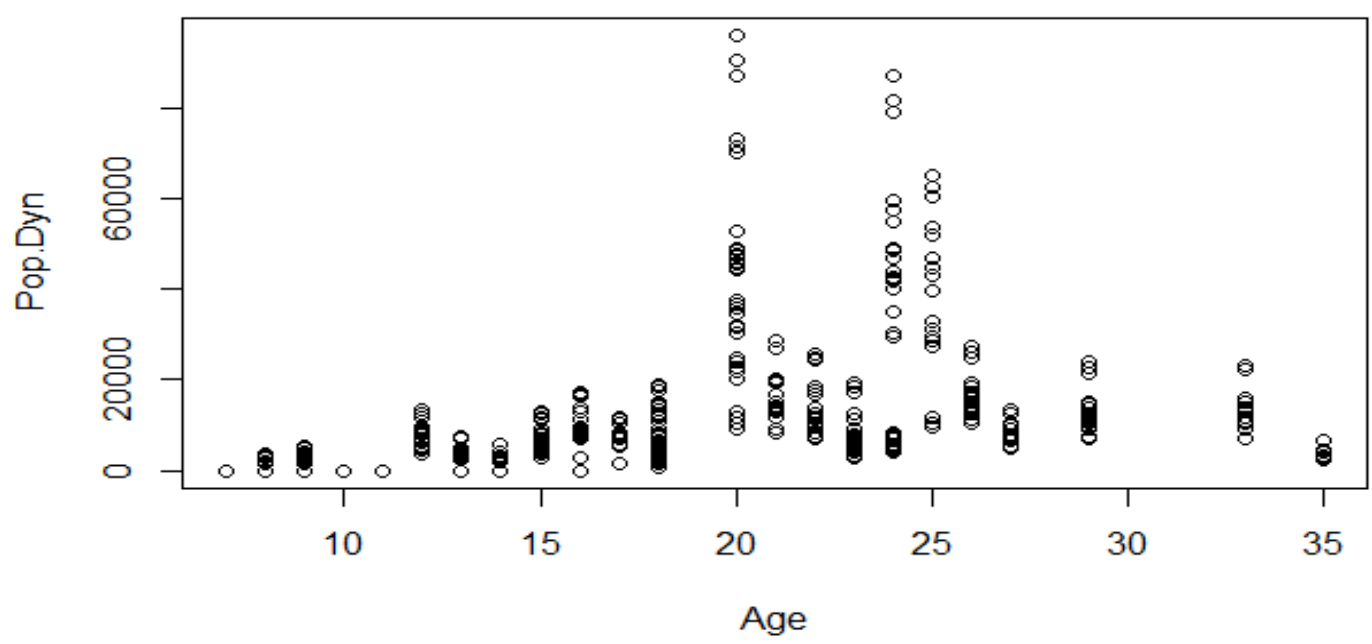

\section{Graph (4.5)}

Graph (4.5) showed maximum population destiny of $T$. semipenetrans of $\mathrm{J} 2$ during survey was recorded in 20-25 years old plants. Then in 10-20 years old plants. Minimum population destiny was recorded in below 10 years old plants.

\section{Temperature Influence on T. semipenetrans Females}

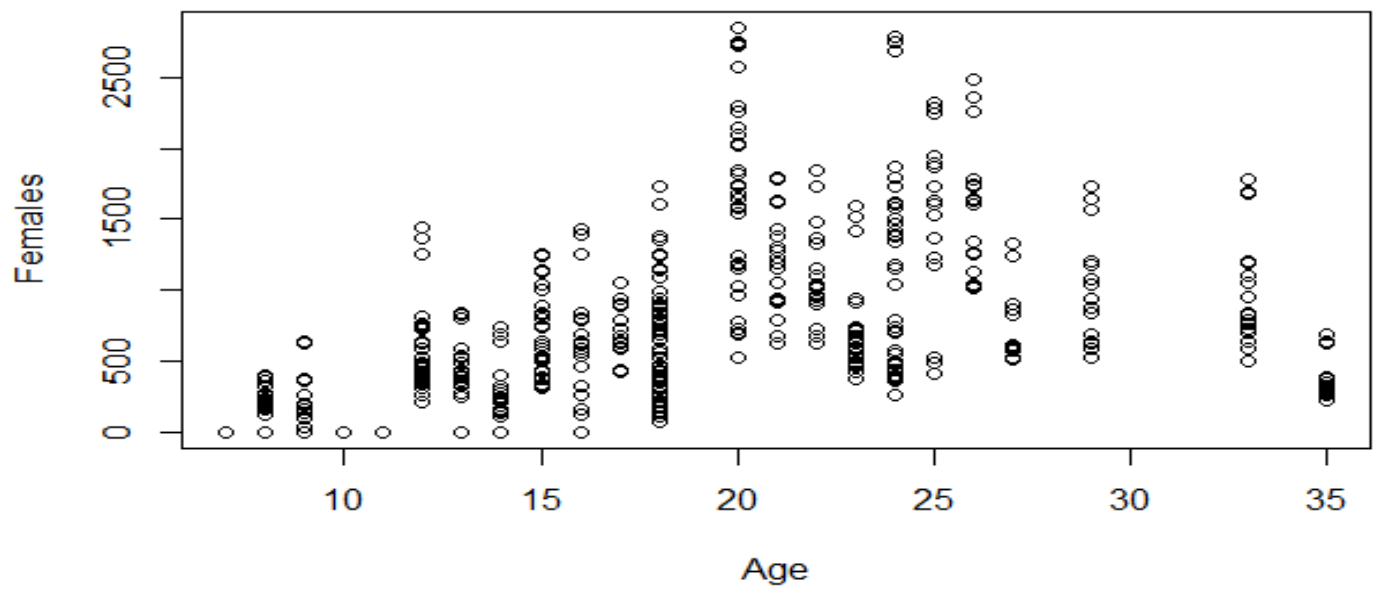

\section{Graph (6.6)}

Graph (6.6) showed maximum population destiny of $T$. semipenetrans of females during survey was recorded in 20-25 years old plants. Then in 10-20 years old plants. Minimum population destiny was recorded in below 10 years old plants. 


\section{Experiment No. 1}

Parameter: No. of Leave

\section{Analysis of Variance}

\begin{tabular}{|c|c|c|c|c|c|}
\hline & Df & SS & MS & F value & $P$ value \\
\hline Varieties & 4 & 3097.8 & 774.4 & 190.09 & $1.85 \mathrm{e}-14$ \\
\hline Treatments & 1 & 1967.8 & 1967.8 & 483 & $1.88 \mathrm{e}-14$ \\
\hline Varieties treatments & 4 & 192.8 & 48.2 & 11.83 & $6.89 e-5$ \\
\hline Residuals & 18 & 73.3 & 4.1 & & \\
\hline
\end{tabular}

Signif. Codes: 0 ‘*** 0.001 “**’ 0.01 “*’ 0.05 ‘’ 0.1 “' 1

Mean and stand tables

\begin{tabular}{|c|c|c|c|c|c|c|}
\hline & Fluter early & kinnow & Musambi & Red blood & Shakri & Treatments \\
\hline Control & $55 \pm 1 \mathbf{c}$ & $80 \pm 1 \mathbf{a}$ & $63 \pm 0 \mathbf{b}$ & $52 \pm 1 \mathbf{c}$ & $42 \pm 1$ d & $57.6 \pm 14.1$ \\
\hline T. semi & $37.3 \pm 1.5 \mathbf{c}$ & $55 \pm 2.6 \mathbf{a}$ & $42 \pm 3.6 \mathbf{b}$ & $39 \pm 2$ bc & $31 \pm 2.5 \mathbf{d}$ & $40 \pm 8.4$ \\
\hline varieties & $46.1 \pm 9.7$ & $67.5 \pm 13.8$ & $47.2 \pm 10.9$ & $45.5 \pm 7.2$ & $36.6 \pm 6$ & $48.71 \pm 14$ \\
\hline
\end{tabular}

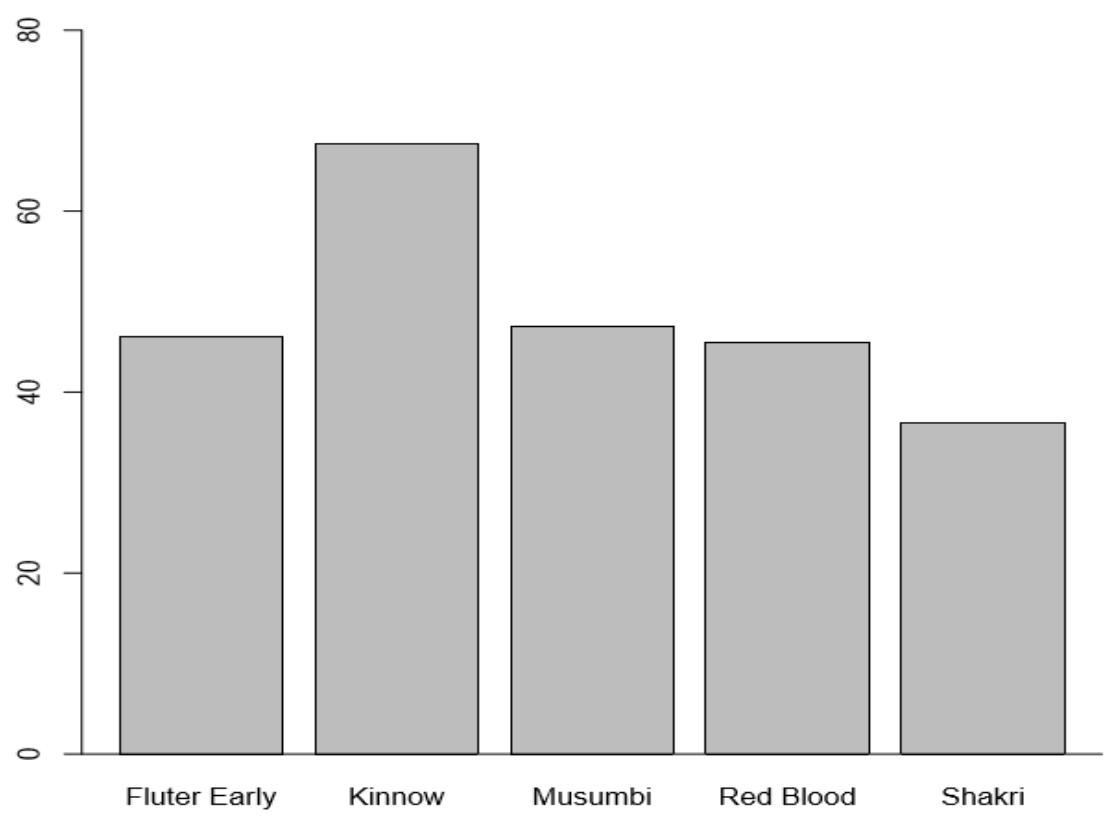

\section{Graph (4.1:1.1)}

In experiment no 1 , only $T$. semipenetrans was inoculated on different varieties. Graph (4.1:1.1) showed that musambi exhibited maximum losses of leaves and red blood minimum losses. 


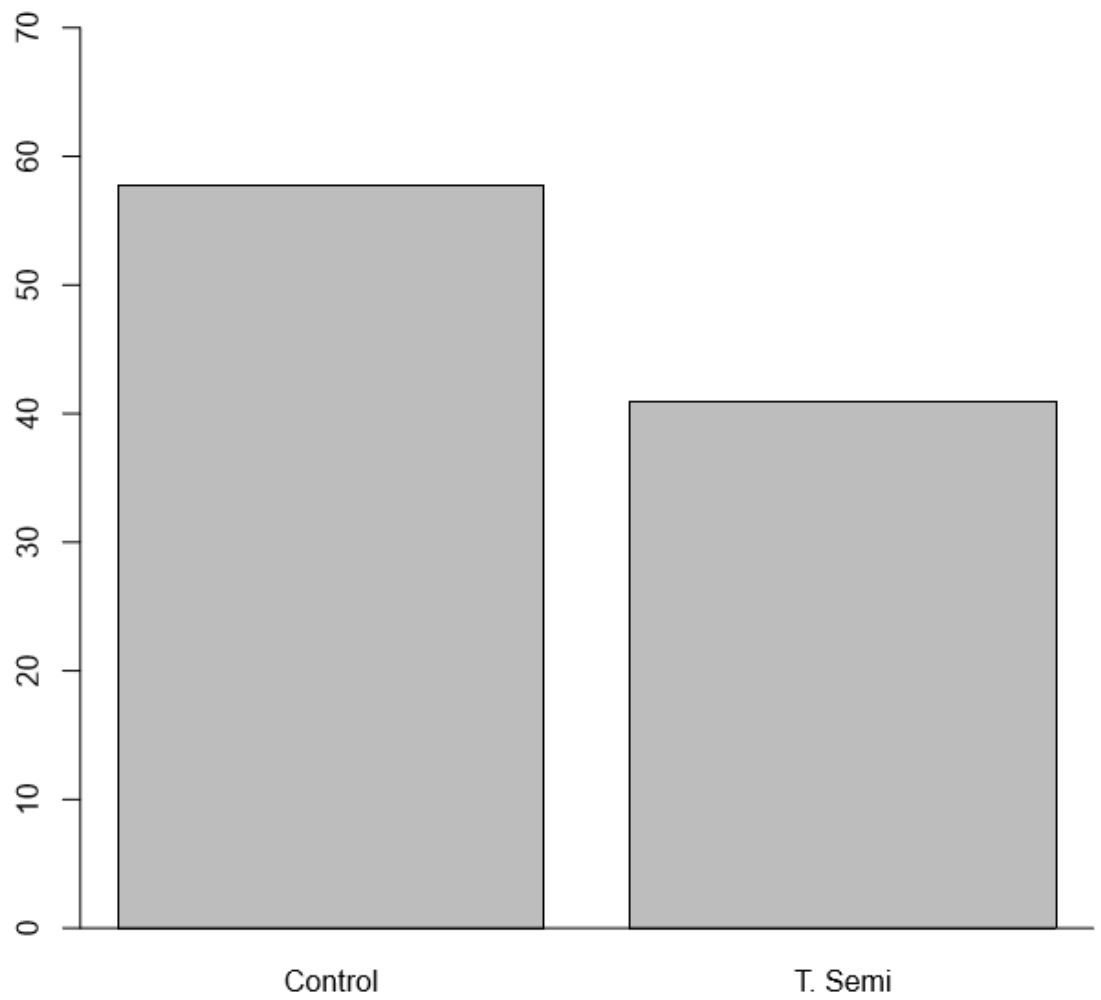

\section{Graph (4.1:1.2)}

Graph (4.1:1.2) showed that maximum leaves were observed in control plants.

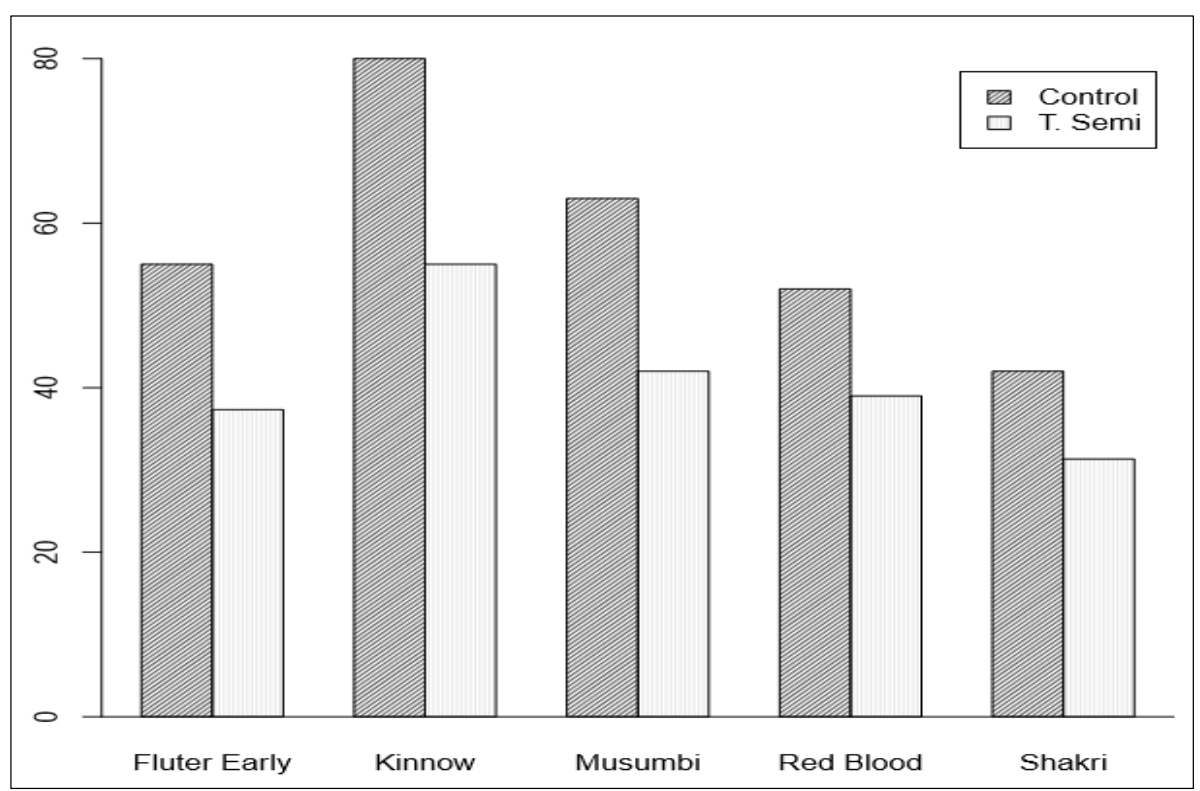

\section{Graph (4.1:1.3)}

Graph showed that maximum leaves were observed in control plants. Feutrel early, kinnow, musambi, red blood and shakri leaves losses were recorded $32 \%, 31 \%, 33 \%, 25 \%$ and $26 \%$ respectively. Maximum loss was recorded in musambi $33 \%$ and minimum loss was recorded in Red blood $25 \%$. 


\section{Parameter: Plant height}

\section{Analysis of variance}

\begin{tabular}{|c|c|c|c|c|c|}
\hline & Df & SS & MS & F value & P value \\
\hline Varieties & 4 & 2.16 & 0.54 & 1.74 & 0.18 \\
\hline Treatments & 1 & 20.0 & 20.0 & 64.42 & $2.34 \mathrm{e}-07$ \\
\hline Varieties treatments & 4 & 0.99 & 0.24 & 0.79 & 0.54 \\
\hline Residuals & 18 & 5.59 & 0.31 & & \\
\hline
\end{tabular}

Signif. Codes: 0 ‘*** 0.001 '**’ 0.01 '*’ 0.05 ‘' 0.1 ' ' 1

Mean and stand tables

\begin{tabular}{|c|c|c|c|c|c|c|}
\hline & Fluter early & Kinnow & Musambi & Red Blood & Treatments \\
\hline Control & $72 \pm 1 \mathrm{e}$ & $77 \pm 1 \mathrm{~d}$ & $85 \pm 0 \mathrm{~b}$ & $88 \pm 1 \mathrm{a}$ & $80 \pm 1 \mathrm{c}$ & $79.6 \pm 6$ \\
\hline T. semi & $49.3 \pm 1.5 \mathrm{e}$ & $54.6 \pm 2 \mathrm{~d}$ & $60 \pm 2.5 \mathrm{~b}$ & $66.6 \pm 1.5 \mathrm{a}$ & $59 \pm 1 \mathrm{c}$ & $58 \pm 6.2$ \\
\hline Varieties & $60.6 \pm 12.4$ & $65.8 \pm 12.3$ & $66.7 \pm 12.33$ & $77.3 \pm 11.7$ & $69.5 \pm 11.5$ \\
\hline
\end{tabular}

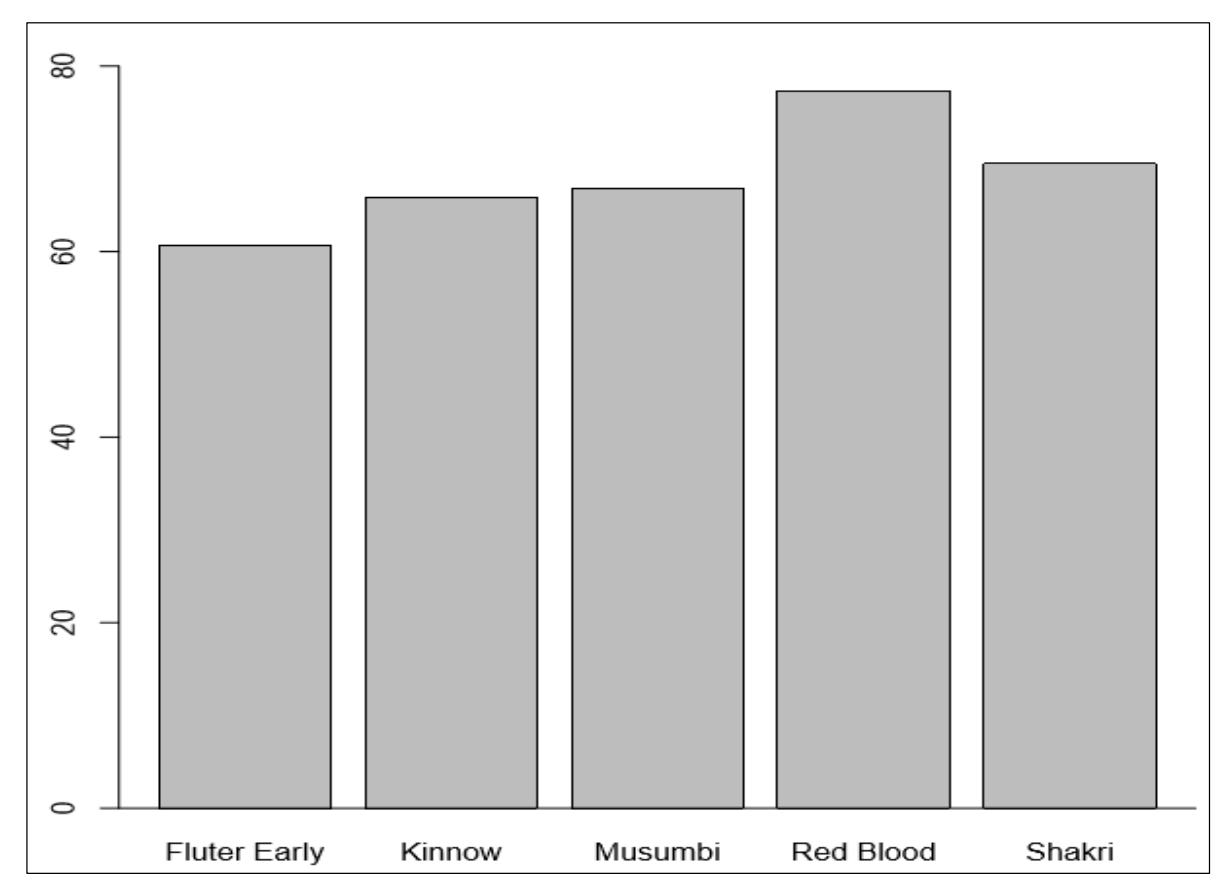

\section{Graph (4.1:1.4)}

Graph (4.1:1.4) showed that feutrel early, kinnow, musambi, red blood and shakri were reduced plant height 31\%, 30\%, $29 \%, 25 \%$ and $26 \%$ respectively. Maximum plant height was recorded in feutrel early, minimum plant height reduction was recorded in feutrel early.

Parameter: No. of J2

\section{Analysis of variance}

\begin{tabular}{|c|c|c|c|c|c|}
\hline & Df & SS & MS & F value & P value \\
\hline Varieties & 4 & 2648176 & 662044 & 22.12 & $9.5 \mathrm{e}-07$ \\
\hline Treatments & 1 & 72244126 & 72244126 & 2414.73 & $2 \mathrm{e}-16$ \\
\hline Varieties treatments & 4 & 350998 & 87750 & 2.93 & 0.049 \\
\hline Residuals & 18 & 538525 & 29918 & & \\
\hline
\end{tabular}

Signif. Codes: 0 ‘*** 0.001 '**’ 0.01 '*’ 0.05 '? 0.1 ' 1 
Mean and stand tables

\begin{tabular}{|c|c|c|c|c|c|c|}
\hline & Fluter early & Kinnow & Musambi & Red Blood & Treatments \\
\hline Control & $0 \pm 0 \mathrm{a}$ & $0 \pm 0 \mathrm{a}$ & $0 \pm 0 \mathrm{a}$ & $0 \pm 0 \mathrm{a}$ & $0 \pm 0 \mathrm{a}$ & $2956 \pm 279.7 \mathrm{c}$ \\
\hline T. semi & $3593 \pm 243.9 \mathrm{a}$ & $3393 \pm 230.5 \mathrm{ab}$ & $3272 \pm 207.4 \mathrm{~b}$ & $3144 \pm 188.2 \mathrm{bc}$ & $3272 \pm 297.7$ \\
\hline Varieties & $1796 \pm 1973$ & $1697 \pm 1864$ & $2454 \pm 1644$ & $1572 \pm 1726$ & $1478 \pm 1628$ & $1753 \pm 1675$ \\
\hline
\end{tabular}

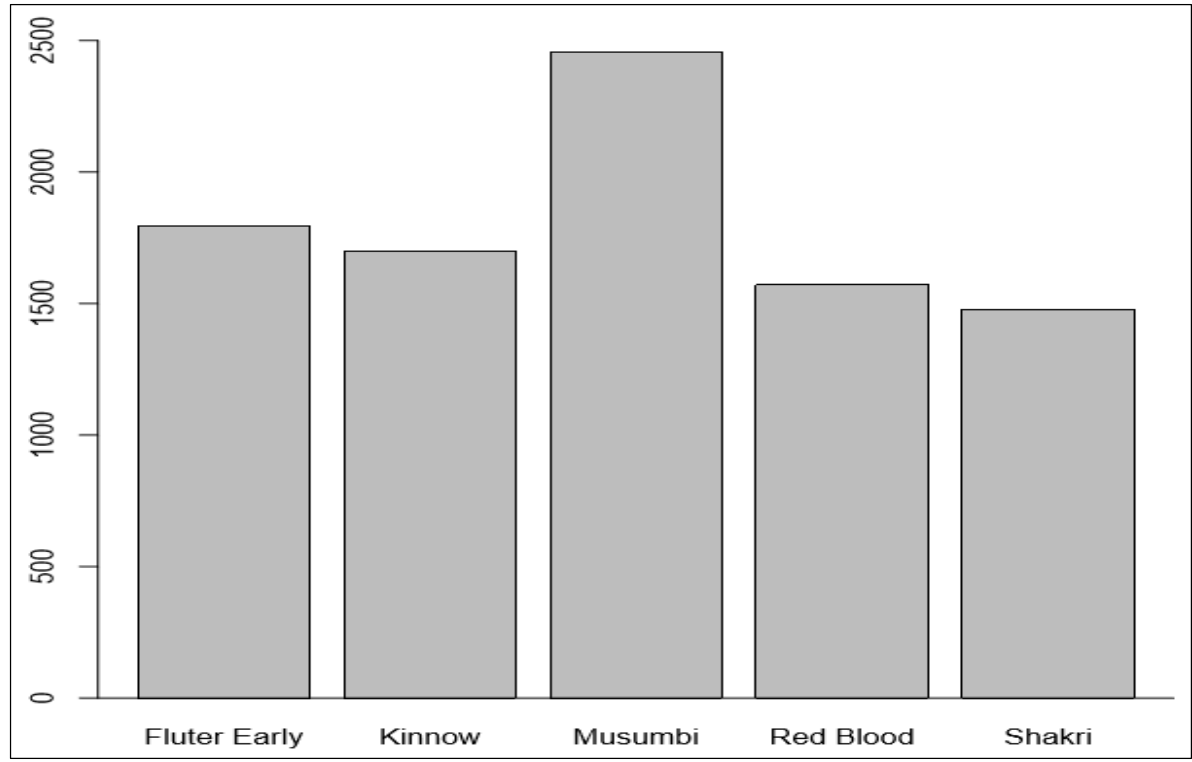

\section{Graph 4.1:1.5}

Maximum population of $T$. semipenetrans $\mathrm{J} 2$ was recorded on feutrel early, minimum population was recorded on shakri.

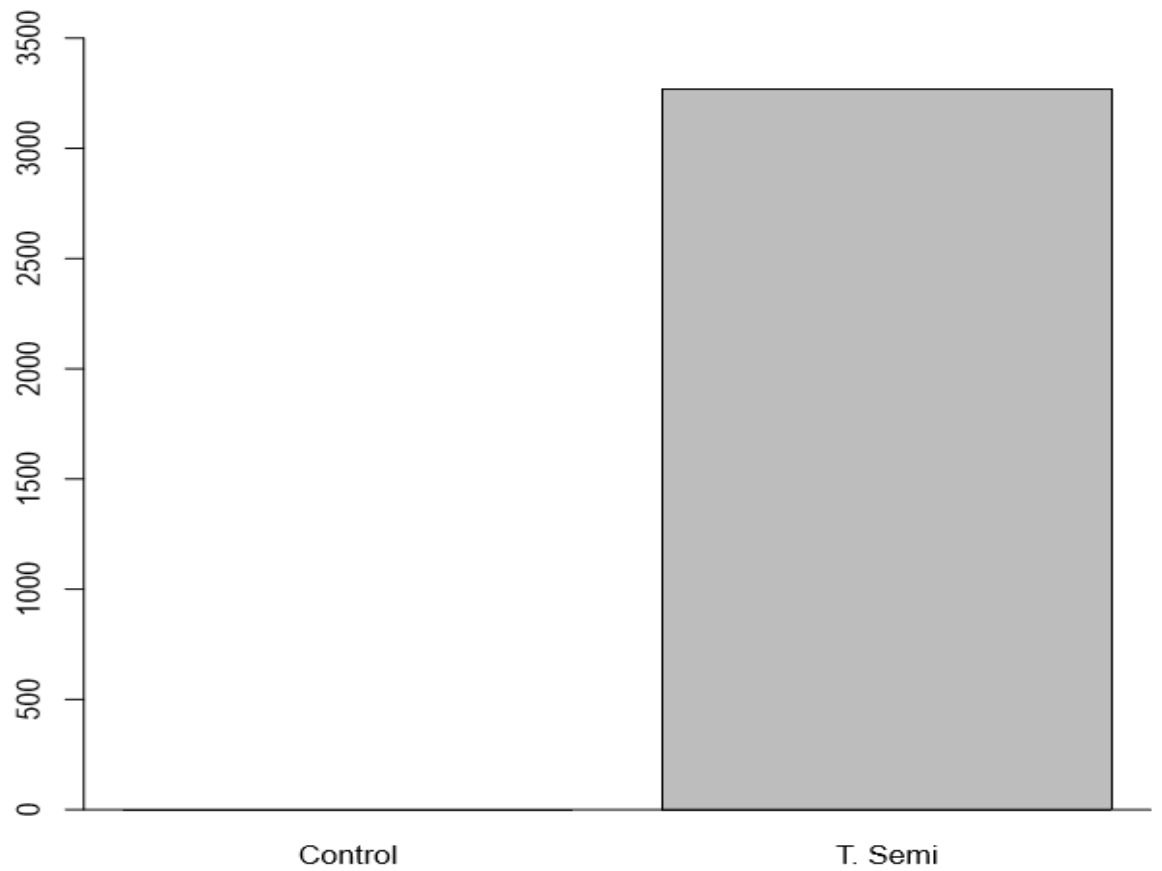

\section{Graph 4.1:1.6}

In control plants no nematode was founded. 


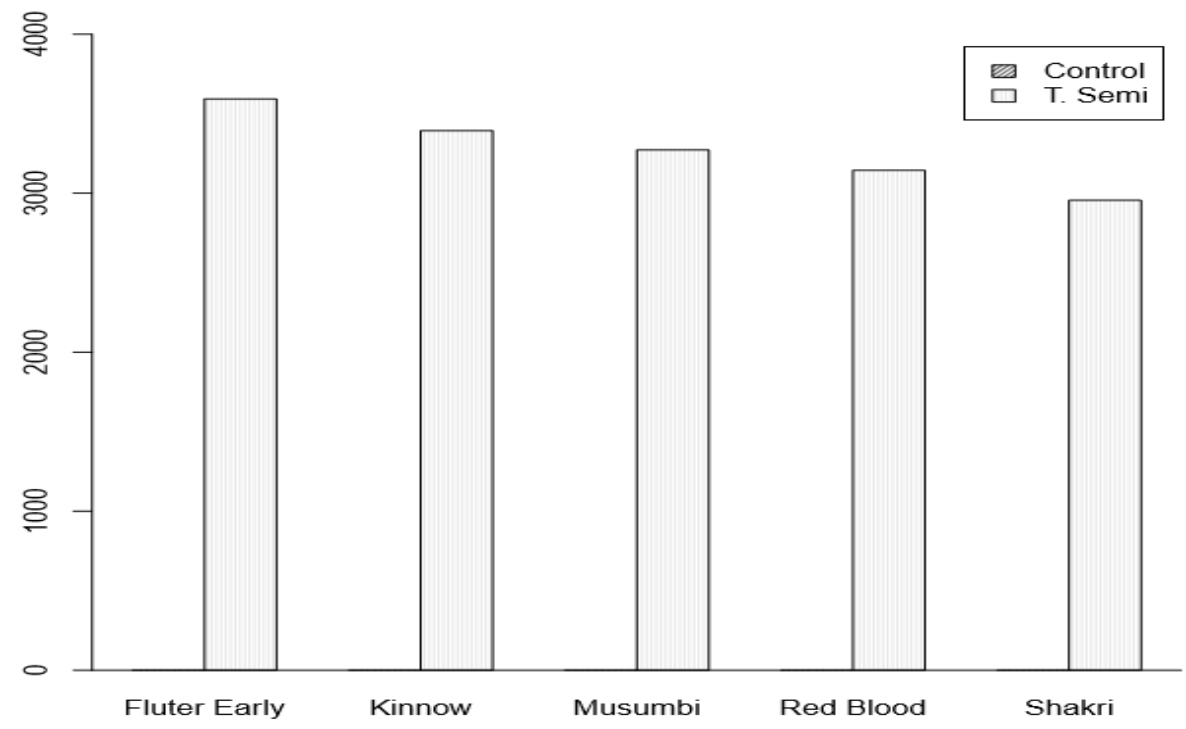

\section{Graph 4.1:1.7}

Maximum population destiny of $T$. semipenetrans was recorded in fluter early 3593 . Minimum population destiny was recorded in shakri 2956.

Parameter: No. of females

Analysis of variance

\begin{tabular}{|c|c|c|c|c|c|}
\hline & Df & SS & MS & F value & P value \\
\hline Varieties & 4 & 117719 & 29430 & 21.85 & $1.04 \mathrm{e}-06$ \\
\hline Treatments & 1 & 1867563 & 1867563 & 1387.10 & $<2 \mathrm{e}-16$ \\
\hline Varieties treatments & 4 & 22874 & 5718 & 4.24 & 0.013 \\
\hline Residuals & 18 & 24235 & 1346 & & \\
\hline
\end{tabular}

Signif. Codes: 0 ‘***’ 0.001 '**’ 0.01 '*’ 0.05 ‘’ 0.1 '’ 1

Mean and stand tables

\begin{tabular}{|c|c|c|c|c|c|c|}
\hline & Fluter early & Kinnow & Musambi & Red Blood & Shakri & Treatments \\
\hline Control & $0 \pm 0 \mathrm{a}$ & $0 \pm 0 \mathrm{a}$ & $0 \pm 0 \mathrm{a}$ & $0 \pm 0 \mathrm{a}$ & $0 \pm 0 \mathrm{a}$ & $0 \pm 0$ \\
\hline T. semi & $577 \pm 56.7 \mathrm{a}$ & $518.7 \pm 41 \mathrm{a}$ & $570.7 \pm 57.3 \mathrm{a}$ & $477.3 \pm 39.5 \mathrm{~b}$ & $446.7 \pm 48 \mathrm{~b}$ & $530 \pm 72$ \\
\hline Varieties & $288.5 \pm 318$ & $290.3 \pm 319$ & $428 \pm 289$ & $238 \pm 2662$ & $223 \pm 246$ & $284.2 \pm 274$ \\
\hline
\end{tabular}




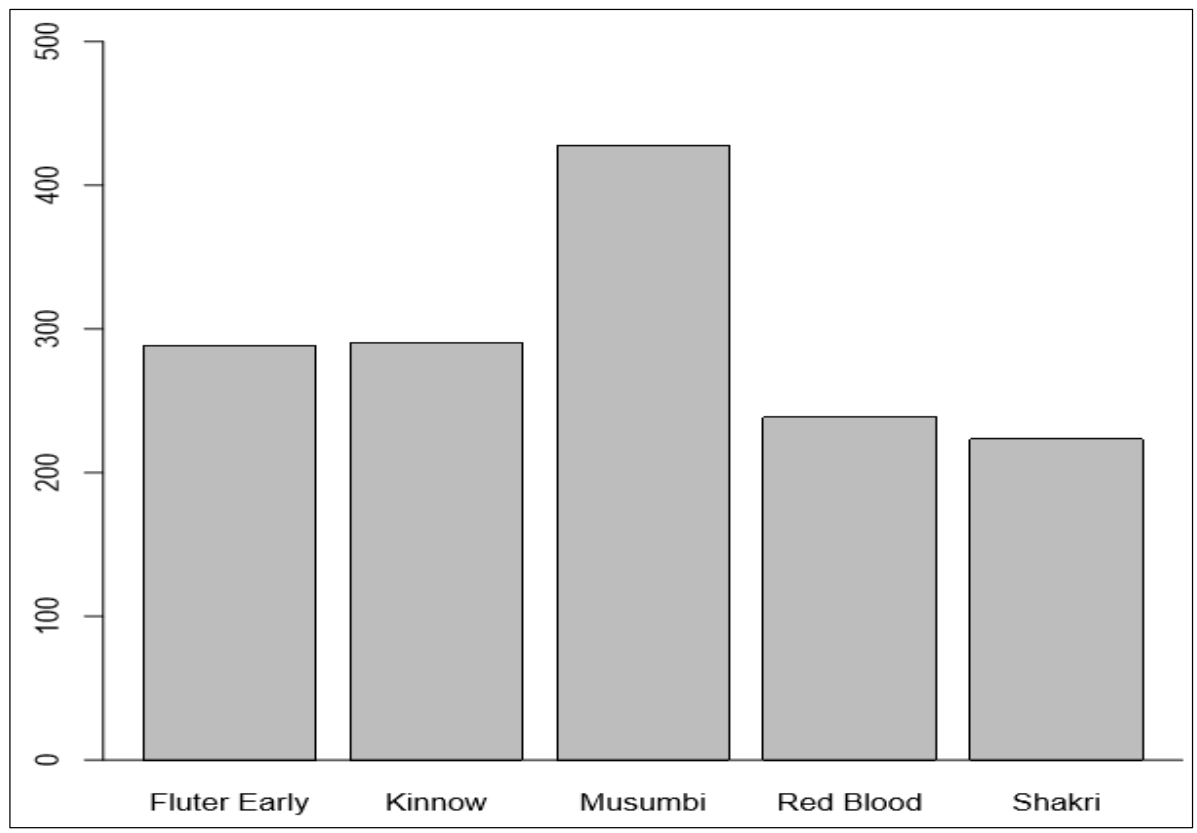

\section{Graph 4.1:4.8}

Maximum T. semipenetrans females were extracted from variety feutrel early. Minimum level was show by shakri.

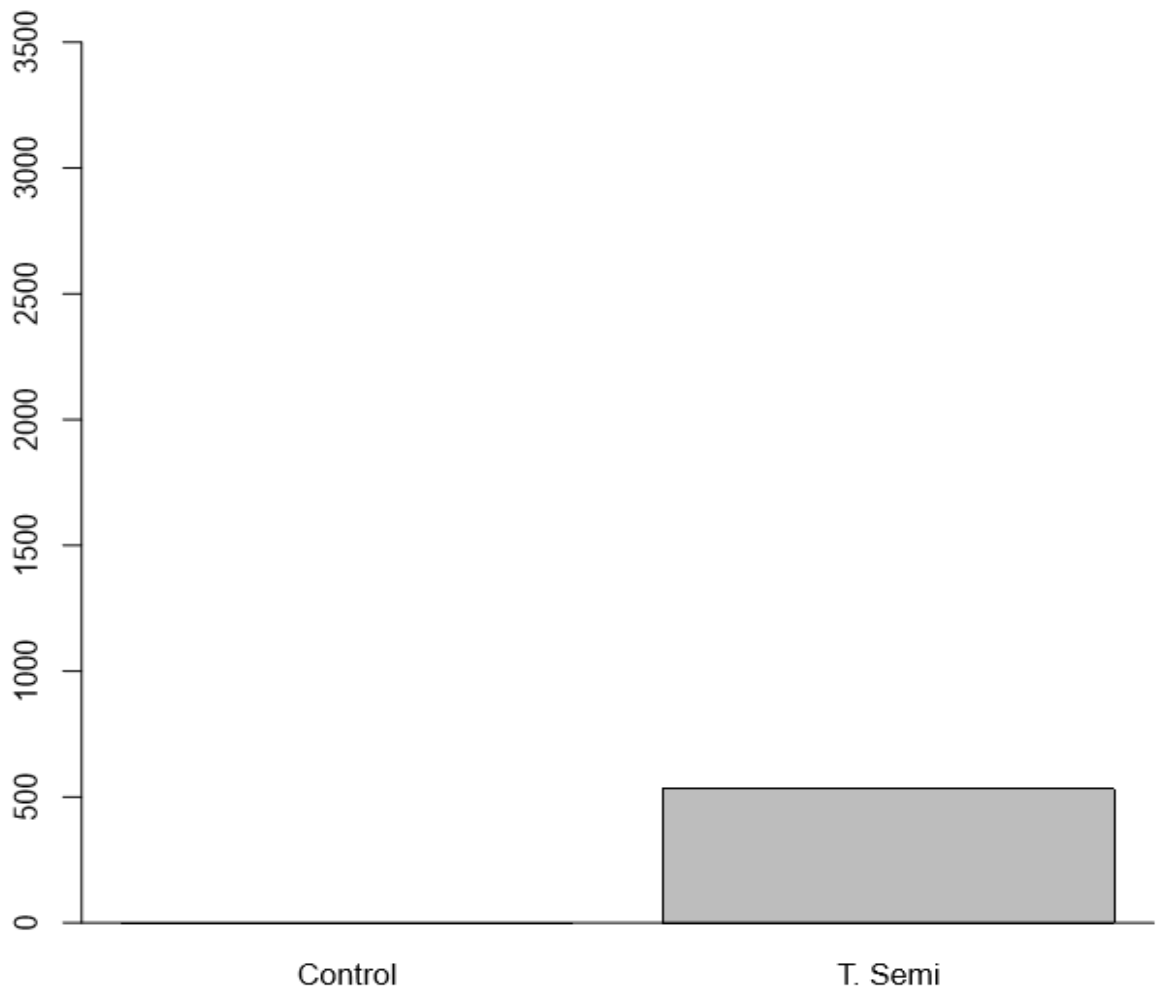

\section{Graph 4.1:1.9}

In control plants no female was recorded 


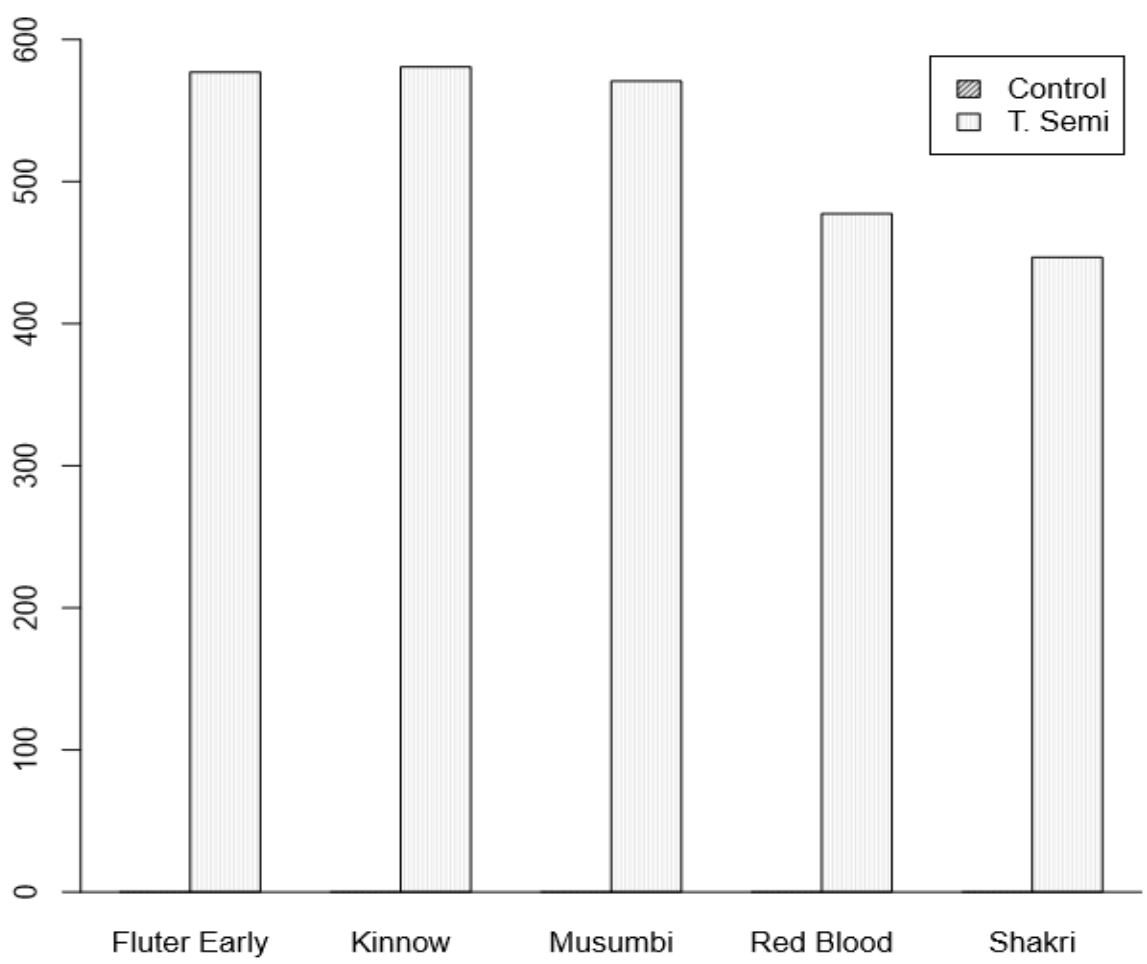

\section{Graph (4.1:10)}

Maximum population destiny of females was recorded in fluter early and minimum population destiny was recorded in shakri.

Parameter: Fresh root wt.

Analysis of variance

\begin{tabular}{|c|c|c|c|c|c|}
\hline & Df & SS & MS & F value & P value \\
\hline Varieties & 4 & 2.16 & 0.54 & 1.74 & 0.18 \\
\hline Treatments & 1 & 20.0 & 20.0 & 64.4 & $2.34 \mathrm{e}-07$ \\
\hline Varieties treatments & 4 & 0.99 & 0.24 & 0.79 & 0.54 \\
\hline Residuals & 18 & 5.5 & 0.31 & & \\
\hline
\end{tabular}

Signif. Codes: 0 ‘**’ 0.001 '**’ 0.01 ‘*’ 0.05 ', 0.1 ' 1

Mean and stand tables

\begin{tabular}{|c|c|c|c|c|c|c|}
\hline & Fluter early & Kinnow & Musambi & Red Blood & Shakri & Treatments \\
\hline Control & $6.8 \pm 0.1 \mathrm{~b}$ & $6.8 \pm 0.10 \mathrm{~b}$ & $7.1 \pm 0 \mathrm{ab}$ & $7.2 \pm 0.1 \mathrm{ab}$ & $7.8 \pm 1.5 \mathrm{a}$ & $7.1 \pm 0.78$ \\
\hline T. semi & $5.3 \pm 0.20 \mathrm{a}$ & $5.33 \pm 0.1 \mathrm{a}$ & $5.46 \pm 0.2 \mathrm{a}$ & $5.66 \pm 0.1 \mathrm{a}$ & $5.4 \pm 0.3 \mathrm{a}$ & $5.44 \pm 0.2 \mathrm{a}$ \\
\hline Varieties & $6 \pm 0.8$ & $6 \pm 0.81$ & $5.8 \pm 0.84$ & $6.43 \pm 0.84$ & $6.6 \pm 1.6$ & $6.23 \pm 1.03$ \\
\hline
\end{tabular}




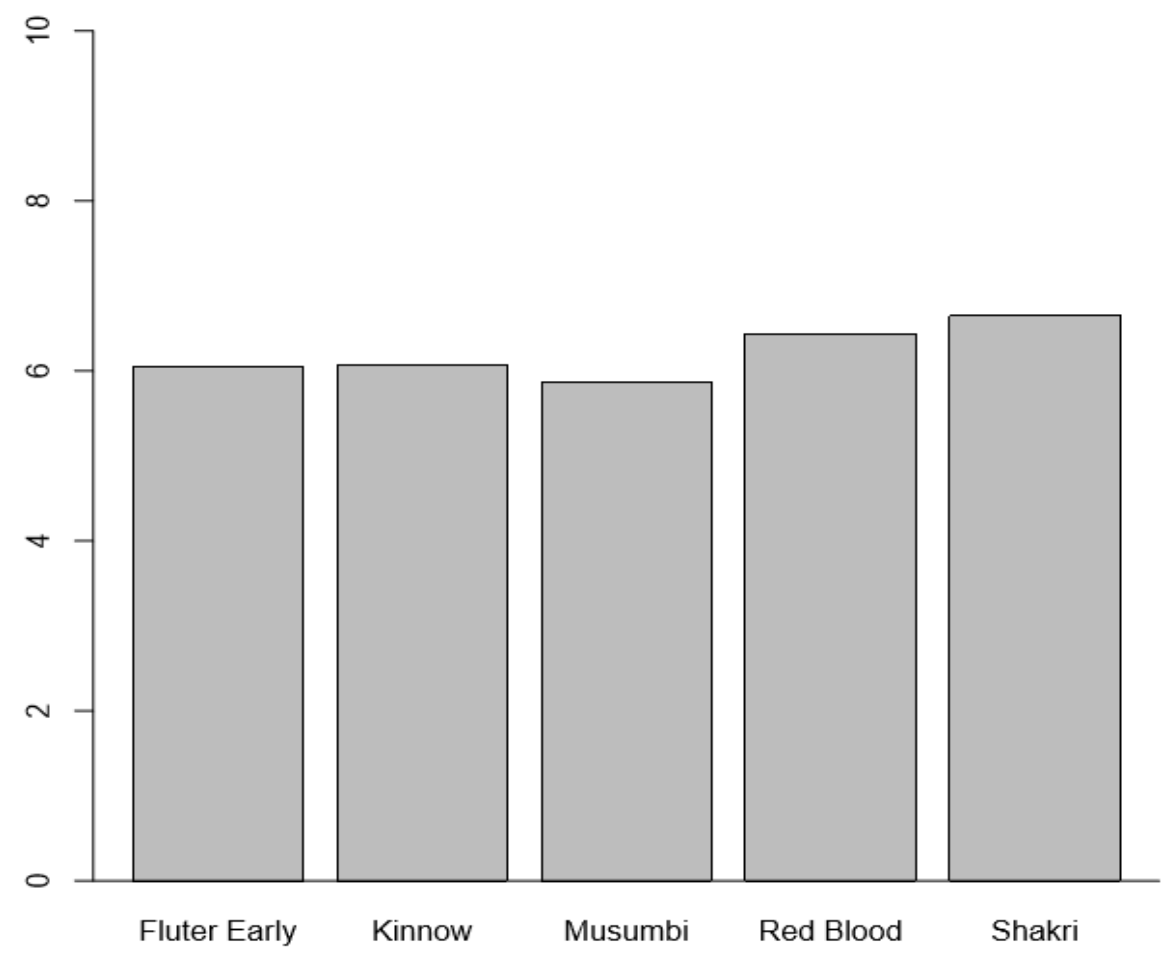

\section{Graph 4.1:11}

Maximum fresh root weight was reduced in musambi 23\%. Minimum root wt. reduction was recorded in shakri $21 \%$.

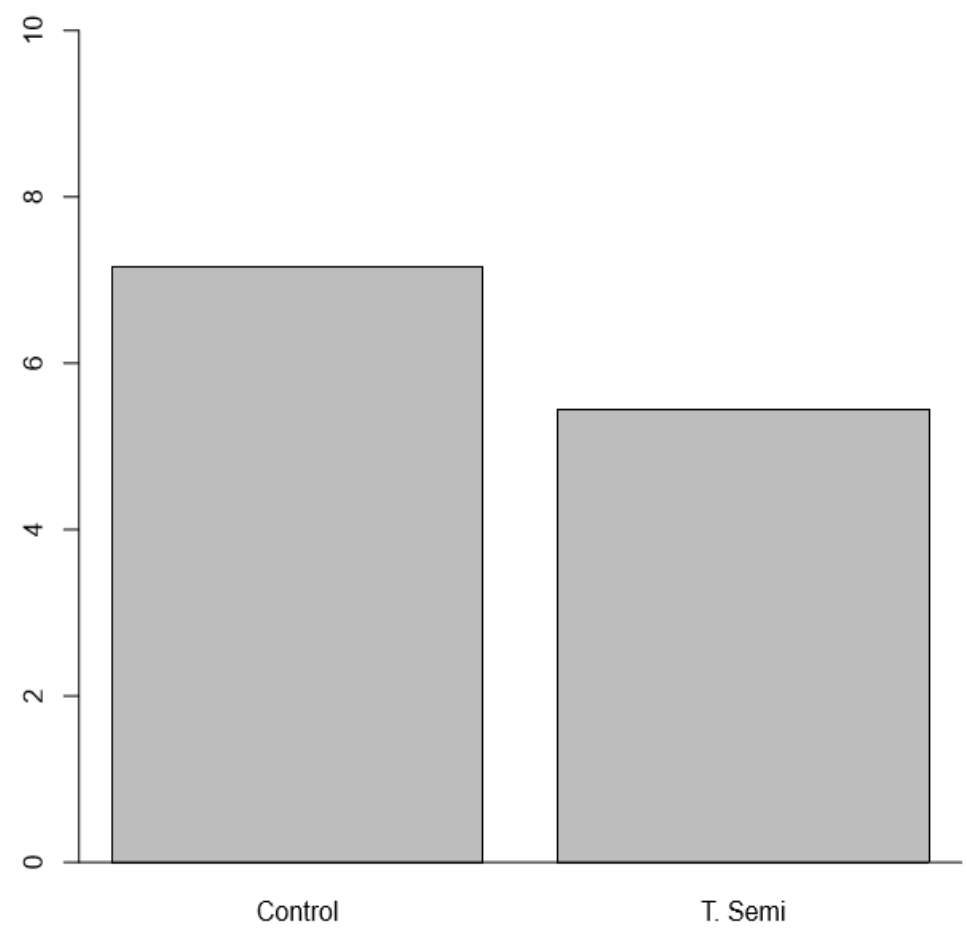

\section{Graph 4.1:12}

As compare with control plants, root weight was losses in inoculated with T. semipenetrans plants. 


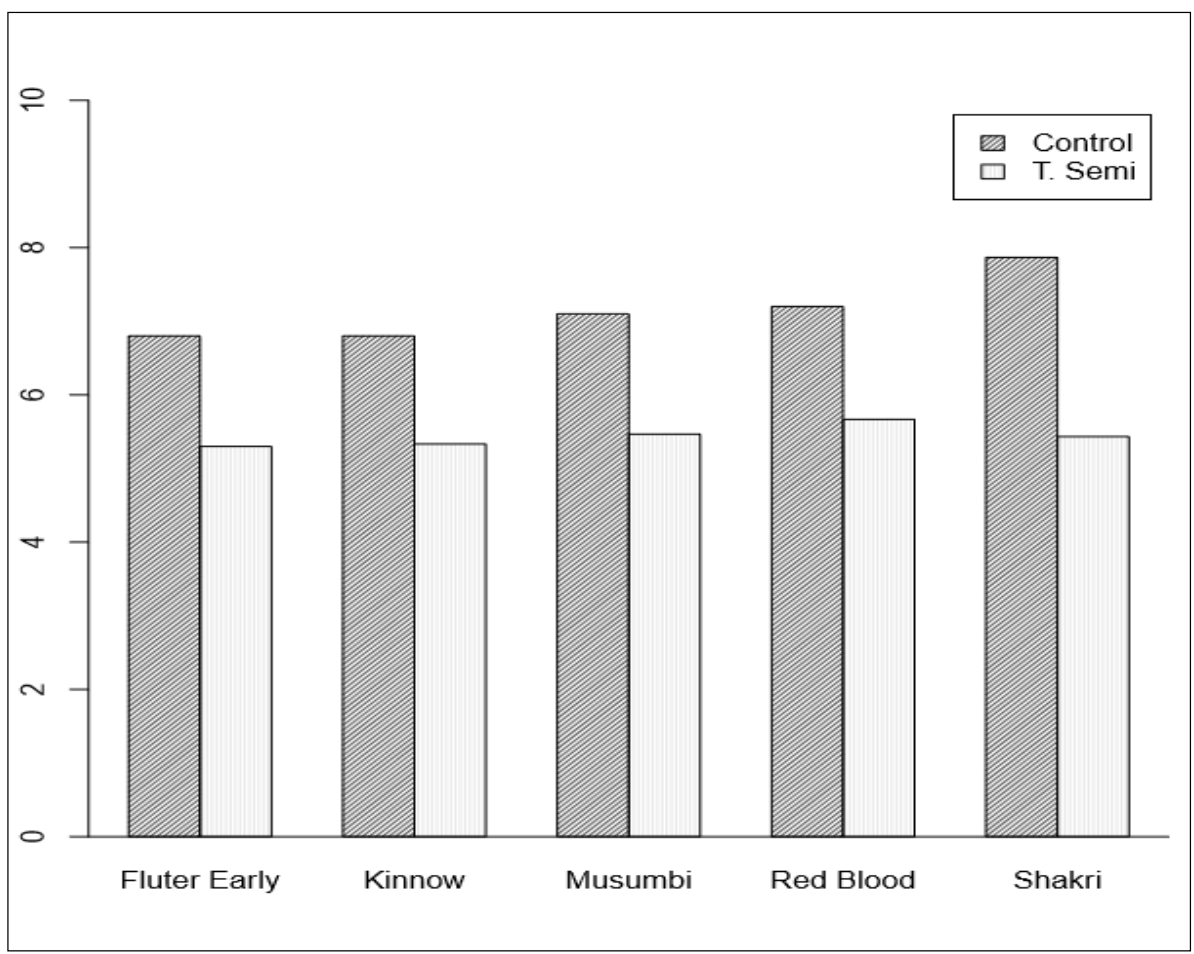

\section{Graph 4.1:13}

Over all, all varieties left their root weight as compared with control plants. Feutrel early, kinnow, musambi, red blood and shakri root wt. reduction was recorded $22 \%, 22 \%, 23 \%, 22 \%$ and $21 \%$ respectively.

\section{Parameter: Fresh shoot wt.}

Analysis of variance

\begin{tabular}{|c|c|c|c|c|c|}
\hline & Df & SS & MS & F value & P value \\
\hline Varieties & 4 & 8.26 & 2.06 & 14.44 & $1.90 \mathrm{e}-05$ \\
\hline Treatments & 1 & 63.9 & 63.7 & 446.1 & $3.74 \mathrm{e}-14$ \\
\hline Varieties treatments & 4 & 0.13 & 0.03 & 0.22 & 0.92 \\
\hline Residuals & 18 & 2.57 & 0.14 & & \\
\hline
\end{tabular}

Signif. Codes: 0 ‘**’ 0.001 '**’ 0.01 '*’ 0.05 ', 0.1 ' 1

Mean and stand tables

\begin{tabular}{|c|c|c|c|c|c|c|}
\hline & Fluter early & Kinnow & Musambi & Red Blood & Shakri & Treatments \\
\hline Control & $16 \pm 1$ & $16.4 \pm 0.15$ & $17.3 \pm 0$ & $17.4 \pm 0.1$ & $17.1 \pm 0.1$ & $16.78 \pm 0.70 \mathrm{a}$ \\
\hline T. semi & $12.9 \pm 0.1$ & $13.43 \pm 0.25$ & $13.9 \pm 0.10$ & $14.3 \pm 0.2$ & $14.2 \pm 0.3$ & $13.75 \pm 0.5 \mathrm{~b}$ \\
\hline Varieties & $14.45 \pm 1.8 \mathrm{c}$ & $14.9 \pm 1.6 \mathrm{~b}$ & $14.7 \pm 1.7 \mathrm{bc}$ & $15.8 \pm 1.7 \mathrm{a}$ & $15.6 \pm 1.6 \mathrm{a}$ & $15.1 \pm 1.6$ \\
\hline
\end{tabular}




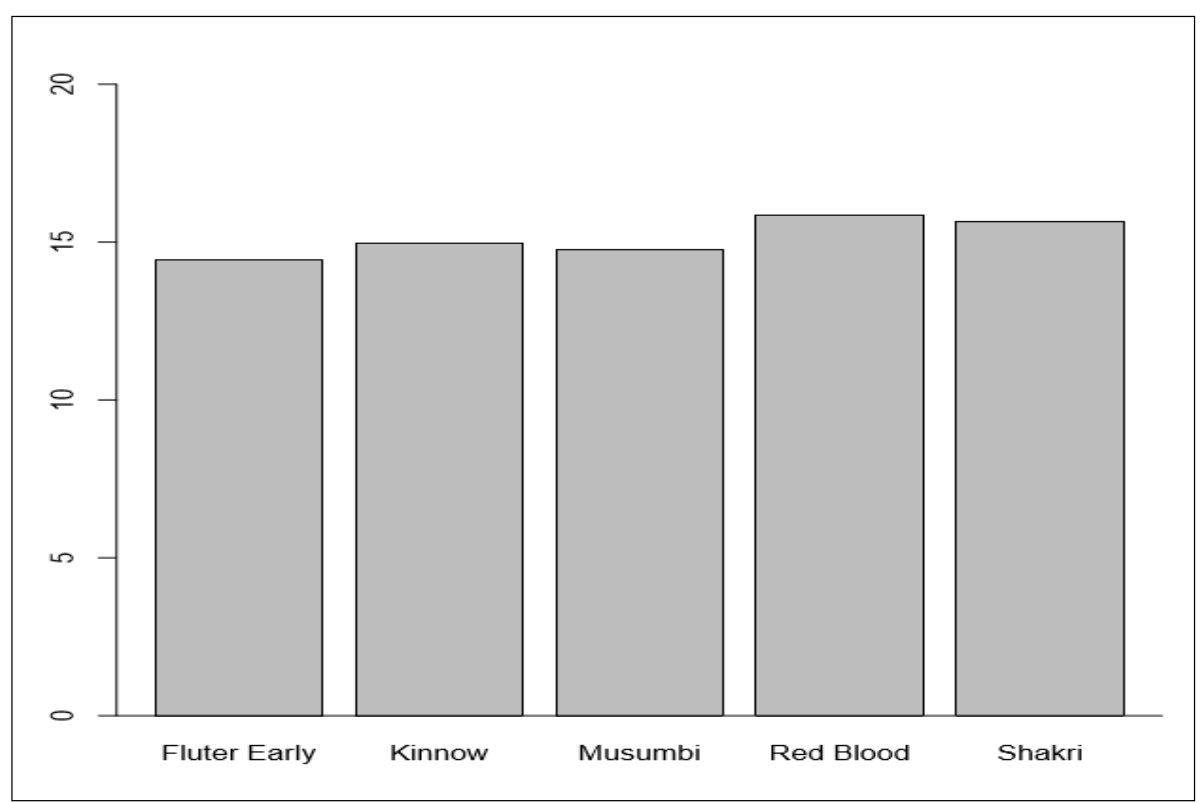

\section{Graph 4.1:14}

Shoot weight was decreased almost same in musambi, feutrel early and kinnow. Red blood shoot weight the minimum as compared to all varieties.

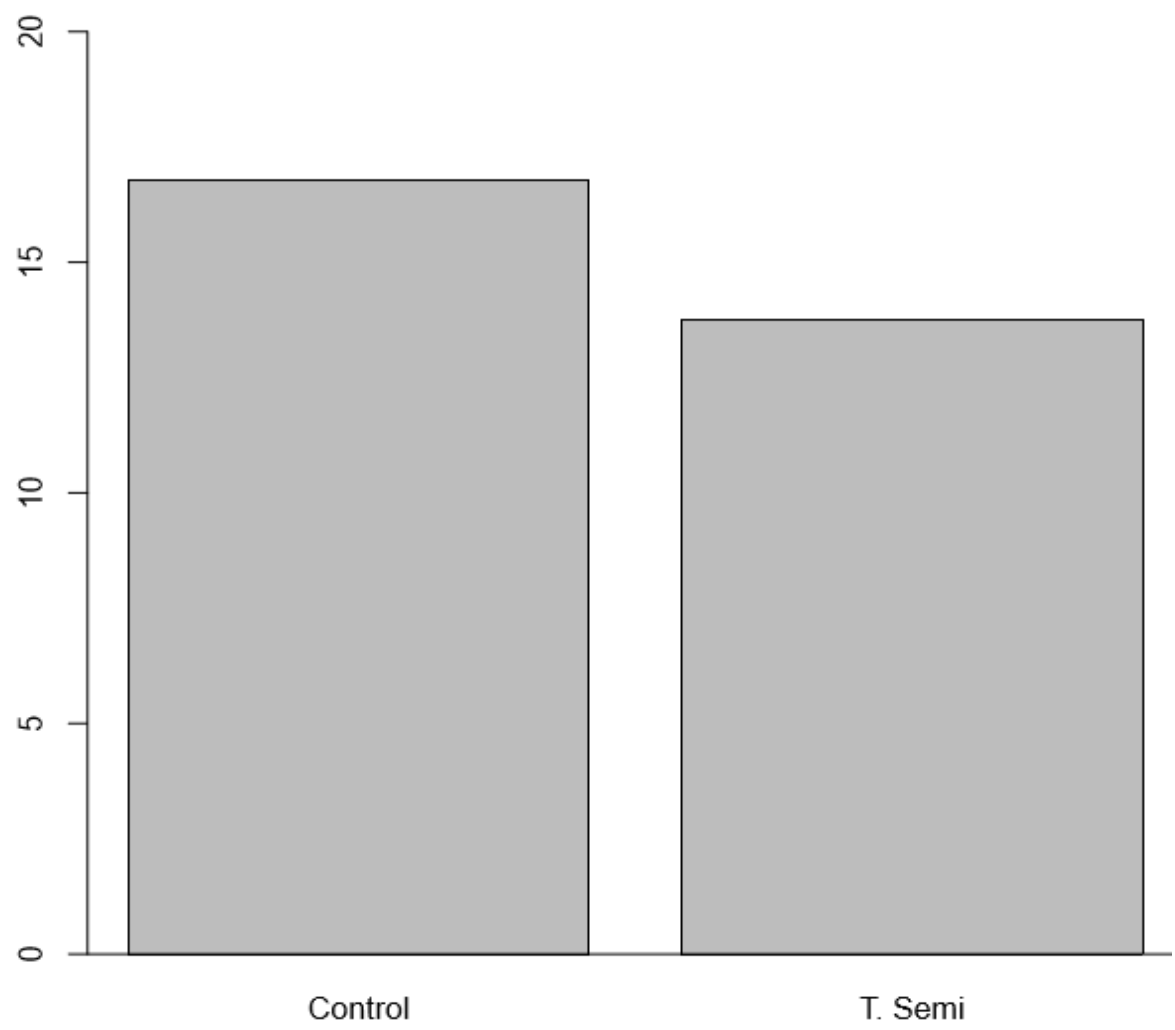

\section{Graph 4.1:15}

In control plants root weight was high as compared to inoculated plants. 


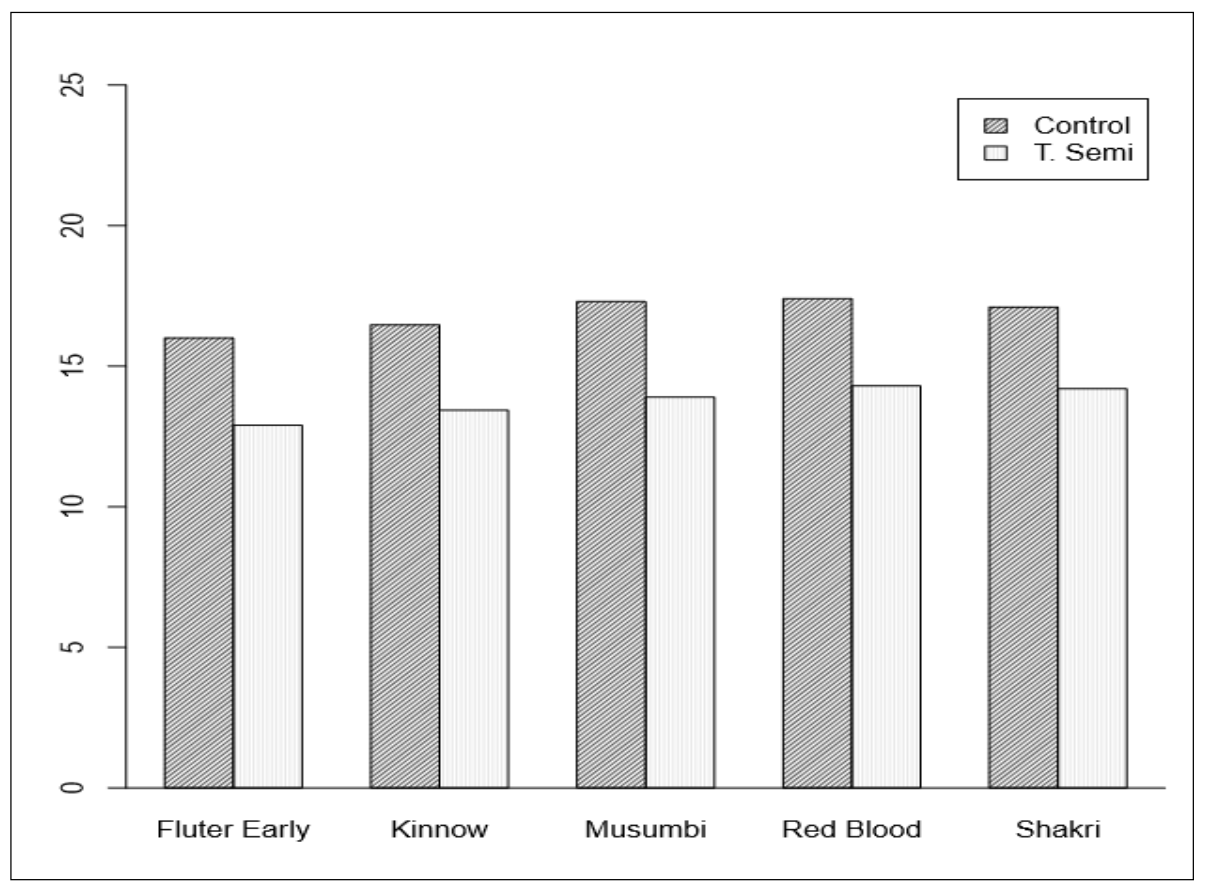

\section{Graph 4.1:16}

Shoot weight in feutrel early, kinnow, musambi, red blood and shakri was decreased 19\%, 18\%, 19\%, 17\% and $17 \%$ respectively.

\section{Discussion}

Observing the occurrence of $T$. semipenetrans in Sargodha district and exploiting the interaction of citrus nematode T. semipenetrans and Fusarium spp. in relation to citrus slow decline, a survey was carried on in different citrus fields of Sargodha district (Sargodha, sillanwali, bhalwal and kot Momin). The orchards were selected randomly from different locations of Sargodha district and 7 to 35 years old orchards were selected. Samples were taken from these orchards 6 times (February, April, June, August, May, July, October, and December). Total 720 samples were taken. Survey results showed that maximum T. semipenetrans occurrence was in tehsil Sargodha (90\%), Kot Momin (80\%), Bhalwal $(60 \%)$ and minimum prevalence was in sillan wali (50\%). Fusarium spp. maximum occurrence was in tehsil Sargodha $(70 \%)$, bhalwal (68\%), Kot Momin (65\%) and sillan wali (60\%). Samples which have both occurrence of $T$. semipenetrans + Fusarium spp. of Sargodha district, Sargodha (70\%), Kot Momin (70\%), Bhalwal (60\%) and sillan wali (40\%).

The survey confirms the occurrence of $T$. semipenetrans in Sargodha District. It's first reported of citrus trees in Californian in 1912 and its description (Cobb 1913). Citrus orchards in south California $90-95 \%$ were infested by $T$. semipenetrans [10]. A survey conducted by Mani et al. [13] of citrus nurseries shown $75 \%$ infestation with $T$. semipenetrans in India. Zhu et al. [11] found 94.7\% infestation in china. Parvez et al. [9]) arranged a survey during 2002 reported 54\% infestation of citrus nematode from Sargodha district while our results shows $70 \%$ infestation which resemble with his results. In the present survey, nematode destiny $\mathrm{J} 2$ and females of roots varied in different areas. The reason is that because many factors affect $T$. semipenetrans destiny and infestation. These include soil texture, temperature, host variety, $\mathrm{pH}$, soil depth, age, nutrients status, moisture. Reproductive rates of different races of nematode obviously vary with rootstock $[6 ; 7]$. Tree age has a great effect on nematode population and distribution [1]. The population of $T$. semipenetrans will increase at temperature $20-31^{\circ} \mathrm{C}$ with maximum destiny at $25^{\circ} \mathrm{C}$ and very slow development at the extremes [5]. Davis [3]) reported that citrus nematode destiny highest in April and declined to lowest levels in August and September. Highest number of nematodes was obtained at $120 \mathrm{~cm}$ distance from the tree trunk up to $30 \mathrm{~cm}$ depth [2]. T. semipenetrans can be found in any soil texture, but greatest damage occurs in shallow, poorly drained soils with organic matter contents from 2-3\% [8]. The present study confirms the presence of citrus nematode in district Sargodha and suggests further intensive survey and measures to control the nematode.

\section{REFERENCE}

[1] Bellow, A., Navas, A. and Clark, C. (1986) "Nematodes of citrus groves in the Spanish Levante: Ecological study focused to their control", Proceedings of Expert's Meeting, Acireale, March 26-29, 1985, In: R. Cavaloro, and E.D. 
Martono (Eds.), Integrated Pest Control in Citrus Groves, A.A. Blackman Publ. Co., Boston, 217-226.

[2] Chawla, M.L. and Sharma, S.B. (1984) "Horizontal and vertical distribution of nematode, Tylenchus semipenetrans", Ind. J. Nematol., 14: 193-195.

[3] Davis, R.M. (1984) "Distribution of Tylenchus semipenetrans in a Texas grape fruit orchard ", J. Nematol., 16: 313-317.

[4] Hamid, G.A., Gundy, S.P., Lovett, C.J. and Van. Gundy, S.D., 1985. Citrus nematode alters carbohydrates partitioning in the "Washington" Navel orange. J. Am. Soc. Hort. Sci., 110: 642- 646.

[5] O’Bannon, J.H., Reynold, H.W. and Leathers, G.R. (1966) "Effects of temperature on penetration, development and reproduction of Tylenchulus semipenetrans", Nematol., 12: 483-487.

[6] O'Bannon, J. H. and Hutchinson D. H. (1974a). Nematode parasites of citrus. In: Luc M., Sikora R.A. and Bridge J. (eds). Plant-parasitic nematodes in subtropical and tropical agriculture. Wallingford, UK: CAB International., pp. 437-466.

[7] O'Bannon, J.H. and Hutchinson, D.H. (1974b) "Development of rootstocks resistant to the citrus nematode, Tylenchulus semipenetrans", In: L.K. Jackson, A.H. Krezdorn and J. Soule (Eds.), Proceedings of 1st International Short Course, September 24-29, 1973, Gainesville, Florida, 22-29.

[8] O'Bannon, J.H. and Essar, R.P. (1985) "Citrus declines caused by nematodes in Florida: I. Soil factors", Florida Department of Agriculture and Consumer Services, Division of Plant Industry, Nematol. Circular No. 14, p. 4.

[9] Parvez, I., Mukhtar, T. and Fiaz, M. (2003). Occurrence of citrus nematode (Tylenchulus semipenetrans) in Sargodha districts. Journal of Research (Science), 14(1): 91-95.
[10] Thorne, G. (1961) "Principles of Nematology", Mc Graw Hill Book Co. Inc. New York. Mani, A., Dakshina, V.M. and Reddy, G.S. (1988) "Distribution of Tylenchus semipenetrans and Meleidogyne javanica in commercial citrus nurseries in Andhra Pradesh", Ind. J. Nematol., 18: 338-339.

[11] Zhu, W.S., Chen, H., Lan, Y.Y. and Qian, K.M. (1992) "Study on citrus nematode disease", Acta Phytopathologica Sinica., 22: 29-33.

[12] Rehman, A., L. Jingdong, A. A. Chandio and Hussain. 2017. Livestock production and population census in Pakistan: Determining their relationship with agricultural GDP using econometric analysis. Information Processing in Agriculture, 4(2): 168-177. Accessed on http://www.sciencedirect.com/science/article/pii/S2214317 316301123

[13] Mani, A., V.M. Dakshina and G.S. Reddy. 1988. Distribution of citrus nurseries in Andhra Pradesh. Indian J. Nematol. 18, 333-339.

[14] Campos, H.D. and V.P. Campos. 2005. Studies on inoculum, inoculation and extraction of root-knot nematodes, Meloidogyne javinaca. Nematol. Brasil. 29(1):75-82.

[15] Eisenback, J.D. and H.H. Triantaphyllou. 1991. Root knot nematodes: Meloidogyne species and races. p. 191-274. In: W.R. Nickle (ed.) Mannual of Agri. Nematol. Marcel Dekker, Inc., NY, USA.

[16] Eisenback, J.D., H. Hirschmann., J.N. Sasser and A.C. Triantaphyllou. 1981. A guide to the four most common species of root knot nematodes, Meloidogyne spp. with a pictorial key. North Carolina State Uni. Graphics and USAID, Raleigh. p. 48.

[17] Jepson, S.B. 1987. Identification of root-knot nematodes (Meloidogyne species). Wallingford, UK, CAB International. 